\title{
A rare giant tubercle of Zuckerkandl with retrosternal extension encountered during total thyroidectomy
}

\author{
Dhalapathy Sadacharan, ${ }^{1,3}$ Shriraam Mahadevan, ${ }^{2,3}$ Sankaran Muthukumar, ${ }^{1}$ \\ Krishnan Ravikumar ${ }^{1}$
}

${ }^{1}$ Department of Endocrine Surgery, Madras Medical College, Chennai, Tamil Nadu, India

${ }^{2}$ Department of Endocrinology, Sri Ramachandra Medical College, Chennai, Tamil Nadu, India

${ }^{3}$ Department of Endocrinology and Endocrine Surgery, Endocrine and Speciality Clinic Chennai, Tamil Nadu, India

\section{Correspondence to} Dr Dhalapathy Sadacharan, drsdhalapathy@gmail.com

Accepted 21 May 2015

\section{(a) CrossMark}

To cite: Sadacharan $D_{\text {, }}$ Mahadevan $S$,

Muthukumar $\mathrm{S}$, et al. BMJ Case Rep Published online: [please include Day Month Year] doi:10.1136/bcr-2015210307

\section{DESCRIPTION}

Tubercle of Zuckerkandl (TZ) is an embryological remnant seen at the site of embryonic fusion of median and lateral anlages of the thyroid gland. TZ is usually present in $50 \%$ of thyroidectomy specimens. The presence of $\mathrm{TZ}$ is considered a constant landmark for identification of recurrent laryngeal nerve (RLN) in the majority of cases. ${ }^{1} \mathrm{TZ}$ is graded according to the size of the tubercle: grade 1 $(<0.5 \mathrm{~cm})$, grade $2(0.6-1 \mathrm{~cm})$ and grade 3 $(>1 \mathrm{~cm}) .^{2}$

We present an extremely rare case of a very large $\mathrm{TZ}$, termed giant $\mathrm{TZ}$, extending into the posterior mediastinum, without retrosternal extension of the primary thyroid lobes. The TZ measured $8.2 \mathrm{~cm}$ in length (figure 1). It was seen extending into the mediastinum posterior to the RLN. The radiographic appearance of a widened retrovisceral space may be useful to detect enlarged TZ preoperatively (figure 2). It is not only the size of the enlarged tubercle that may cause widening of the prevertebral soft tissue space, but equally important, the location, either a complete retrotracheal or retrooesophageal extension. ${ }^{3}$ To the best of our knowledge, this is the first reporting of a giant TZ with a retrosternal extension. This entity is unusually rare and, if not recognised, could result in recurrent laryngeal nerve injury. Complete removal of this entity is essential; a total thyroidectomy can prevent residual thyroid tissue in the neck, which can be a source of recurrence of toxic goitres and thyroid malignancy if not adequately addressed.

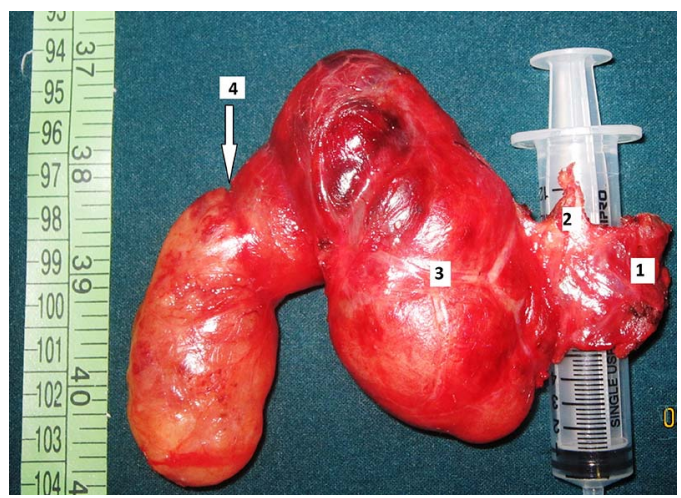

Figure 1 Operative specimen of total thyroidectomy showing (1) left lobe, (2) pyramidal lobe, (3) right lobe, (4) giant tubercle of Zuckerkandl, measuring $8.2 \mathrm{~cm}$, arising from the right lobe, which was delivered from the mediastinum by a cervical approach.

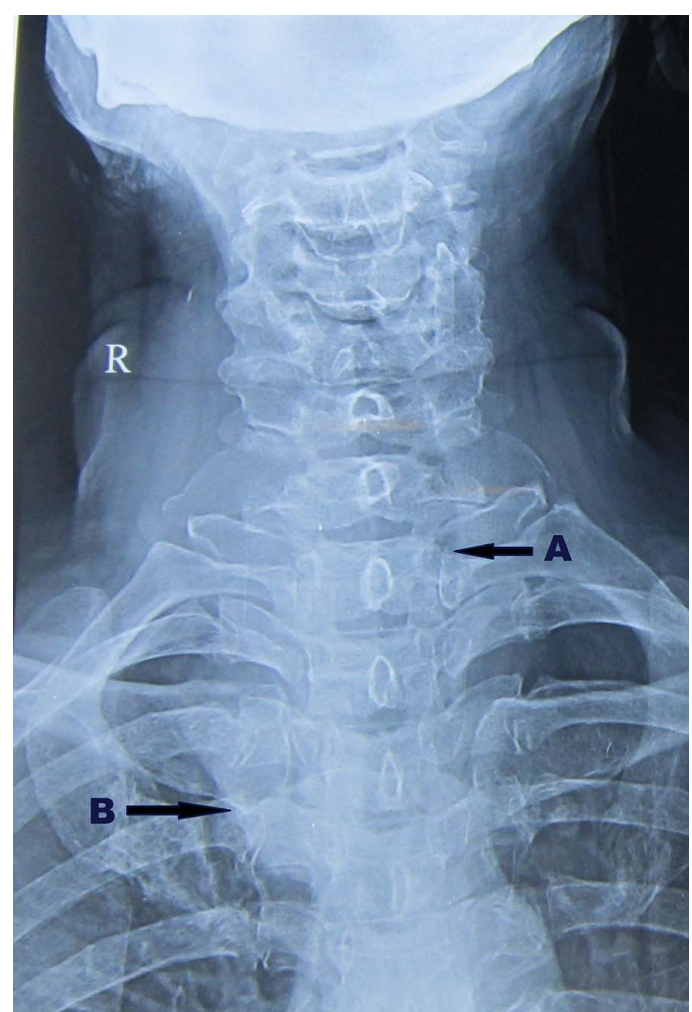

Figure 2 Skiagram of the neck and upper chest showing (A) gross tracheal deviation to the left, (B) soft tissue shadow causing mediastinal widening due to the retrosternal extension of the giant tubercle of Zuckerkandl on the right.

\section{Learning points}

- Tubercle of Zuckerkandl is an important landmark for identification of recurrent laryngeal nerves during thyroidectomy, with around $90 \%$ of nerves coursing medial to the tubercle.

- These giant tubercles of Zuckerkandl can make the identification of the recurrent laryngeal nerves difficult.

- Recognising this rare entity of giant tubercle of Zuckerkandl moving retrosternally, will add to surgical acumen and patient safety.

Patient consent Obtained. 


\section{Images in...}

Provenance and peer review Not commissioned; externally peer reviewed.

\section{REFERENCES}

1 Toniato A, Mazzarotto R, Piotto A, et al. Identification of the nonrecurrent laryngeal nerve during thyroid surgery:20year experience. World J Surg 2004;28(7):659-61.
2 Pelizzo MR, Toniato A, Gemo G. Zuckerkandl's tuberculum: an arrow pointing to the recurrent laryngeal nerve (constant anatomical landmark). J Am Coll Surg 1998;187:333-6.

3 Hishan AN, Sarojah A, Mastura T, et al. Prevertebral soft tissue measurements in thyroid enlargement: the value of lateral neck radiographs. Asian J Surg 2004;27:172-5.

Copyright 2015 BMJ Publishing Group. All rights reserved. For permission to reuse any of this content visit http://group.bmj.com/group/rights-licensing/permissions.

BMJ Case Report Fellows may re-use this article for personal use and teaching without any further permission.

Become a Fellow of BMJ Case Reports today and you can:

- Submit as many cases as you like

- Enjoy fast sympathetic peer review and rapid publication of accepted articles

- Access all the published articles

- Re-use any of the published material for personal use and teaching without further permission

For information on Institutional Fellowships contact consortiasales@bmjgroup.com

Visit casereports.bmj.com for more articles like this and to become a Fellow 